\title{
Mercury and methylmercury concentration assessment in children's hair from Manaus, Amazonas State, Brazil
}

\author{
Luciana A. FARIAS ${ }^{1}$, Déborah I. T. FÁVARO ${ }^{1}$, Artemiza PESSOA², Jaime P. L. AGUIAR², \\ Lúcia K. O. YUYAMA²
}

\section{ABSTRACT}

The present study evaluated $\mathrm{Hg}$ and $\mathrm{MeHg}$ content in hair samples of 201 children 2 to 7 years old, living in six neighborhoods of the city of Manaus, Amazonas State, Brazil. In general, the total $\mathrm{Hg}$ and $\mathrm{MeHg}$ median ranges in hair were similar $(0.91$ to $\left.1.71 \mathrm{mg} \mathrm{kg}^{-1}\right)$ except for the São Jose neighborhood, which was lower $\left(0.16 \mathrm{mg} \mathrm{kg}^{-1}\right)$. De spite the fact that the Manaus population consumes fish as part of the normal dietary intake, the $\mathrm{Hg}$ hair levels were below the level for an adult population not exposed to mercury $\left(2.0 \mathrm{mg} \mathrm{kg}^{-1}\right)$. These data were compared to demographic, socioeconomic information and eating habits of the families that took part in the study. The results were also compared to other published data from the Amazon region, other regions of Brazil and other countries. Future studies to set $\mathrm{Hg}$ and $\mathrm{MeHg}$ levels in hair of children in Brazil should take into account and assess the diversity of the country, mainly in terms of eating habits, socio-economic and cultural aspects.

KEYWORDS: mercury, methylmercury, children's hair, Amazon region.

\section{Avaliação da concentração de Mercúrio e Metilmercúrio em cabelo de crianças de Manaus, Estado do Amazonas, Brasil}

\section{RESUMO}

O presente estudo avaliou o teor de $\mathrm{Hg}$ e $\mathrm{MeHg}$ em amostras de cabelo de 201 crianças de 2 aos 7 anos de idade, residentes em seis bairros da cidade de Manaus, Amazonas, Brasil. Em geral, o teor de $\mathrm{Hg}$ total e $\mathrm{MeHg}$ em cabelo foram semelhantes (medianas de 0,91 a $1,71 \mathrm{mg} \mathrm{kg}^{-1}$ ), exceto para o bairro São José, que foi menor $\left(0,16 \mathrm{mg} \mathrm{kg}^{-1}\right)$. Apesar da população de Manaus consumir peixe como parte da dieta normal, os níveis de $\mathrm{Hg}$ nos cabelos ficaram abaixo do nível para uma populaçáo adulta náo exposta ao mercúrio $\left(2,0 \mathrm{mg} \mathrm{kg}^{-1}\right)$. Esses dados foram comparados com informaçóes demográficas, socioeconômicas e hábitos alimentares das famílias que participaram do estudo. Os resultados também foram comparados com outros dados publicados da Amazônia, outras regiôes do Brasil e outros países. Futuros estudos para definir os níveis de $\mathrm{Hg}$ total e $\mathrm{MeHg}$ no cabelo das crianças brasileiras deveráo considerar e avaliar a diversidade do país, principalmente em termos de hábitos alimentares, nível sócio-econômico e os aspectos culturais.

PALAVRAS-CHAVE: mercúrio, metilmercúrio, cabelos de crianças, região Amazônica

1 Instituto de Pesquisas Energéticas e Nucleares, IPEN-CNEN/SP, São Paulo, SP. Av. Professor Lineu Prestes 2242, CEP 05508-000, São Paulo, SP, Brasil, Fone: (11) $3133-9977$. FAX: E-mail: lufarias2@yahoo.com.br

2 Instituto Nacional de Pesquisas da Amazônia, INPA, Av. André Araújo, 2936, Aleixo, CEP 69060-001, Manaus - AM, Brasil, E-mail: yuyama@inpa.gov.br 


\section{INTRODUCTION}

Many recent studies of fish consumers in Europe and America have revealed significant associations between fish consumption and $\mathrm{Hg}$ and methylmercury ( $\mathrm{MeHg}$ ) levels (Roulet et al. 1997; Santos et al. 2000; Guentzel et al. 2007; Marques et al. 2007; Passos et al. 2007; Díez et al. 2008; Endo and Haraguchi 2010; Freire et al. 2010).

In the Amazon, $\mathrm{Hg}$ exposure through fish consumption has been the subject of much concern over the last two decades. A large number of exposure assessments of fish-eating populations have been conducted in many parts of the huge Amazon region, using blood and/or hair as biomarkers to study communities environmentally exposed through their fish diet (Campos 2001; Dorea 2003; Dorea et al. 2005; Santos et al. 2007; Hacon et al. 2008; Passos and Mergler 2008; Passos et al. 2008). Fish has always been an important item in the diet for Amazonians and per se is their best source of essential nutrients. However, the social and economic transformations that have been taking place in the region over the last decades have contributed to changes in the dietary habits of these populations. The increased availability of industrialized food in the more developed cities can affect the $\mathrm{Hg}$ levels in hair, which is associated with dietary habits.

According to the Brazilian Family Budget Survey - POF 2002-2003 (IBGE - the Brazilian National Census) (IBGE 2004), the poorest communities in Brazil, such as indigenous groups, riverine populations and coastal area dwellers consume fish as their main protein source. Communities of a higher economic class have more protein options to choose from and thus generally do not need to consume large amounts of fish for protein.

The objective of the present study was to assess total $\mathrm{Hg}$ and $\mathrm{MeHg}$ content in hair samples of 201 children, aged 2 to 7 years old, living in six neighborhoods of the city of Manaus, Amazon, and attempt to establish correlations of $\mathrm{Hg}$ levels in hair with fish intake consumption reported in the POF 2002-2003. These data were compared to demographic, socioeconomic information and eating habits of the families that took part of the study. The results were also compared to other published studies from the Amazon region, other regions of Brazil and other countries.

Furthermore, this study furnishes more information about $\mathrm{Hg}$ values in hair and eating habits from Manaus and other regions of the country.

\section{MATERIALS AND METHODS}

\section{Study design and sampling location}

Manaus, the capital of the Amazonas State, is located in the North of Brazil, and belongs to one of the world's largest ecological region. Official data puts the population at 1.802.014 inhabitants (IBGE 2010). The city is located on the banks of the Negro River, which is a black water river and receives drain water from the Amazon ecosystem.

In 2003 the project "Food Security/Insecurity in Manaus" was under development and coordinated by the National Institute of Amazonian Research - INPA (Segall-Correa et al 2003). The sampling process was based on IBGE census (2000) according to spatial configuration of urban population of Manaus in zones and the most representative neighborhoods in each zone. From these considerations the six most populous neighborhoods of the city were chosen for the study, those being: Alvorada - West-Central zone; Cidade Nova - North zone; Compensa - West zone; Flores - South-Central zone; Japiim - South zone; São José Operário - East zone (Figure 1). Eight hundred and ninety four (894) families from these neighborhoods were interviewed of which 626 families were constituted of people below 18 years, and from this group, 268 were preschool children from 2 to 7 years old (children's group). The study was approved by the Ethics Committee of the National Institute of Amazonian Research (INPA).

Hair samples (201) of the present study were taken from this previous study in 2003, as part of a "Food Safety Study in Manaus" project coordinated by INPA and total and methylmercury were assessed. The study was also approved by the Ethics Committee of the Institute of Nuclear and Energy Research (IPEN/CNEN-SP) (Protocol n. 100/2005-CEP/ IPEN/SP).

For eating habits and fish intake of the families, the IBGE (the Brazilian census) POF 2002-2003 (Family Budget Survey) (IBGE 2004) was used. These data details the quantity of food and beverages each household consumes, according to great Brazilian regions, and divided in rural and urban areas as well.

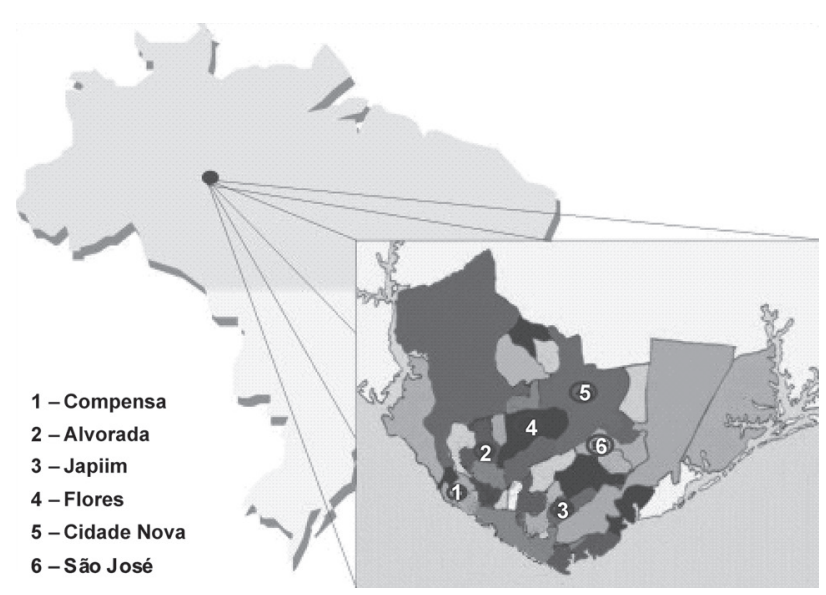

Figure 1 - Map of Manaus and neighborhoods sampled of the city. 
The mothers and/or guardians of the children were interviewed in order to obtain relevant demographic and socioeconomic data. ABPE score (Brazilian Association of Research Companies) was used for social classification. This classification uses education level of the head of the household; number of radios at home; number of refrigerators; washing machines and color TVs; availability of drinking water and sewage. ABEP scores vary from zero (the poorest) to 34 (the richest). The scores were transformed into social class categories. Scores from 0 to 5 correspond to class E, 6 to 10 (class D), 11 to 16 (class C), 17 to 20 (class B2), 21 to 24 (class B1), 25 to 29 (class A2) and the richest from 30 to 34 (class A) (ABEP 2003).

\section{Sampling and sample preparation}

Hair samples were collected from donors with a single cut from the occipital region very close to the scalp with steel scissors, in the approximate amount of $1 \mathrm{~g}$, when possible. The cleaning procedure followed the recommended protocol by the International Atomic Energy Agency (IAEA 1987). About 30 samples of children's hair were collected in each neighborhood. For chemical analysis hair samples were sent to the Neutron Activation Analysis Laboratory from IPEN/ CNEN-SP.

\section{Fish most consumed for Manaus population}

Farias et al. (2010) analyzed the fish species most consumed by the Manaus population. The fish species evaluated were: Aracu (Schizodar sp), Aruanã (Osteoglossum bicirrhossum), Branquinha (Curimata laticeps), Curimatá (Prochilodus nigricans), Jaraqui (Prochilodus insignis sp), Pacu (Mylossoma spp), Pescada (Plagioscion spp), Pirapitinga (Piractus brachypomum), Sardinha (Triportheus elongatus spp), Surubim (Pseudoplalystoma fasciatum), Tambaqui (Colossoma macropomum) and Tucunaré (Cichla ocellaris spp). All samples were analyzed in natura and then cooked using three different cooking processes. The $\mathrm{Hg}$ losses during the cooking processes were then evaluated. Details of this study were published in a previous paper (Farias et al. 2010). The mean and standard deviation for total $\mathrm{Hg}$ concentration in natura for these 12 fish species was $750 \pm 773 \mu \mathrm{g} \mathrm{kg}^{-1}\left(30-2392 \mu \mathrm{g} \mathrm{kg}^{-1}\right.$; median, $393 \mu \mathrm{g} \mathrm{kg}^{-1}$ ) (dry weight).

\section{Total mercury and methylmercury determination}

Mercury $(\mathrm{Hg})$ and methylmercury $(\mathrm{MeHg})$ determination were performed using Cold Vapor Atomic Absorption Spectrometry (CV AAS), using a FIMS from Perkin Elmer. The analytical procedure used (wet digestion) was that of Horvat (1996) with some modifications. For total Hg determination hair samples were digested in a mixture of concentrated $\mathrm{HNO}_{3}$ and $\mathrm{H}_{2} \mathrm{SO}_{4}$ in Teflon vials, put into an aluminum block at 90 ${ }^{0} \mathrm{C}$ for 3 hours. For $\mathrm{MeHg}$ determination, the methodology was based on the leaching of the sample with $6 \mathrm{M} \mathrm{HCl}$, separation of organic from inorganic $\mathrm{Hg}$ through an ionic exchange resin used to separate non-ionic $\mathrm{Me}-\mathrm{HgCl}$ from a $\mathrm{HgCl}_{4}^{2-}$ complex, retained on the column. After separation, samples were digested in a mixture of $\mathrm{HNO}_{3}$ and $\mathrm{H}_{2} \mathrm{SO}_{4}$ and $\mathrm{Hg}$ determination done by CV AAS. The methodology validation for total $\mathrm{Hg}$ and $\mathrm{MeHg}$ determinations were carried out by reference material analyses IAEA-085 (Human Hair) and IAEA-086 (Human Hair - unspiked). Relative standard deviation ranged from 2.6 to $3.6 \%$ and 2.2 to $6.2 \%$; and relative errors were $1.0 \%$ and ranged from 0.4 to $1.5 \%$ for total $\mathrm{Hg}$ and $\mathrm{MeHg}$ respectively, showing good precision and accuracy for both methodologies.

\section{Statistical analyses}

The statistical analysis was performed by the software Statistica Student Version 6.0 (Tulsa, OK, USA).

Descriptive statistics were used to characterize the studied population, as well as, $\mathrm{Hg}$ exposure. Inter-group comparisons were performed using nonparametric techniques.

The Shapiro Wilks test was applied to verify normality distribution of the total $\mathrm{Hg}$ data in each studied neighborhood and revealed a non normal distribution pattern. Thus, the non parametric Kuskal-Wallis test was applied to ascertain that the differences were not significant ( $\mathrm{p}>0.05)$.

Kruskal-Wallis showed that the differences in the $\mathrm{Hg}$ medians observed in function of neighborhoods were not significant ( $p>0.05)$, as were the observed differences of the medians in function of social classes.

The box plot was used to verify data distribution for social class sub groups.

\section{RESULTS AND DISCUSSION}

\section{Results}

The total $\mathrm{Hg}$ and $\mathrm{MeHg}$ levels in the hair samples from the six different Manaus neighborhoods are shown in Table 1.

The distribution of mercury content in children's hair for the whole study population is shown in Figure 2; the total average content was $1.93 \pm 3.90 \mathrm{mg} \mathrm{kg}^{-1}$ (range: 0.02 $-34.4 \mathrm{mg} \mathrm{kg}^{-1}$ ). Hair mercury content were lower than the US EPA reference limit (USEPA 2005) of $1 \mathrm{mg} \mathrm{kg}^{-1}$ in 50.2 $\%$ of the studied children; $26.9 \%$ presented levels between 1 and $2 \mathrm{mg} \mathrm{kg}^{-1}$. The range of mercury level in the hair for an adult population unexposed recommended by the World Health Organization (WHO) is $1-2 \mathrm{mg} \mathrm{kg}^{-1}$. However, those who consume fish once or more times per day may have mercury levels in hair exceeding $10 \mathrm{mg} \mathrm{kg}^{-1}$ (WHO 2008). Furthermore, $20.9 \%$ showed levels higher than 2 and lower than $14 \mathrm{mg} \mathrm{kg}^{-1}$, and $2.0 \%$ of the studied children had levels higher than the Benchmark Lower Limit Dose (BMDL) for 
Table 1 - Total mercury $\left(\mathrm{mg} \mathrm{kg}^{-1}\right)$ (mean \pm s.d.; median; interval) and methylmercury $(\%)$ in hair samples of the children from the Manaus city

\begin{tabular}{|c|c|c|c|c|c|c|c|}
\hline \multirow[t]{2}{*}{$\begin{array}{l}\text { Manaus } \\
\text { Neighborhoods }\end{array}$} & \multicolumn{3}{|c|}{$\begin{array}{l}\mathrm{Hg}_{\text {total }} \\
\text { Mean } \pm \text { S.d. } \\
\text { (interval) } \\
\text { (n) }\end{array}$} & \multicolumn{3}{|c|}{$\begin{array}{l}\mathrm{Hg}_{\text {total }} \\
\text { median }\end{array}$} & \multirow{2}{*}{$\begin{array}{c}\mathrm{MeHg} \\
\text { (Proportion in relation to } \\
\text { total } \mathrm{Hg} \text { content - \%) } \\
\text { (interval) }\end{array}$} \\
\hline & $\begin{array}{c}\text { Total } \\
\text { (male+female) }\end{array}$ & Female & Male & $\begin{array}{c}\text { Total } \\
\text { (female + male) }\end{array}$ & Female & Male & \\
\hline Alvorada & $\begin{array}{c}2.3 \pm 3.8 \\
(0.28-18.27) \\
(22)\end{array}$ & $\begin{array}{c}2.55 \pm 4.49 \\
(0.47-18.27) \\
(15)\end{array}$ & $\begin{array}{c}1.75 \pm 1.94 \\
(0.28-6.04) \\
(07)\end{array}$ & 1.23 & 1.22 & 1.29 & 47 to 97 \\
\hline Cidade Nova & $\begin{array}{c}2.8 \pm 3.8 \\
(0.10-20.09) \\
(31)\end{array}$ & $\begin{array}{c}2.63 \pm 4.53 \\
(0.10-20.09) \\
(18)\end{array}$ & $\begin{array}{c}3.04 \pm 2.53 \\
(0.41-9.37) \\
(13)\end{array}$ & 1.71 & 1.62 & 2.12 & 47 to 95 \\
\hline Compensa & $\begin{array}{c}1.5 \pm 1.6 \\
(0.02-8.64) \\
(40)\end{array}$ & $\begin{array}{c}1.16 \pm 0.98 \\
(0.07-3.90) \\
(26)\end{array}$ & $\begin{array}{c}2.03 \pm 2.28 \\
(0.02-8.64) \\
(14)\end{array}$ & 1.16 & 0.98 & 1.19 & 47 to 95 \\
\hline Flores & $\begin{array}{c}3.2 \pm 7.6 \\
(0.19-34.36) \\
(33)\end{array}$ & $\begin{array}{c}1.22 \pm 0.94 \\
(0.23-3.96) \\
(19)\end{array}$ & $\begin{array}{c}5.92 \pm 11.23 \\
(0.19-34.36) \\
(14)\end{array}$ & 0.98 & 0.97 & 1.52 & 48 to 90 \\
\hline Japiim & $\begin{array}{c}1.4 \pm 1.4 \\
(0.05-7.14) \\
(44)\end{array}$ & $\begin{array}{c}1.30 \pm 1.20 \\
(0.05-4.79) \\
(26)\end{array}$ & $\begin{array}{c}1.67 \pm 1.58 \\
(0.12-7.14) \\
(18)\end{array}$ & 1.06 & 0.89 & 1.57 & 49 to 97 \\
\hline São José & $\begin{array}{c}0.7 \pm 1.2 \\
(0.06-4.66) \\
(31)\end{array}$ & $\begin{array}{c}0.69 \pm 0.95 \\
(0.06-2.94) \\
(16)\end{array}$ & $\begin{array}{c}0.79 \pm 1.42 \\
(0.06-4.66) \\
(15)\end{array}$ & 0.16 & 0.14 & 0.18 & 54 to 98 \\
\hline
\end{tabular}

(n) - number of samples.

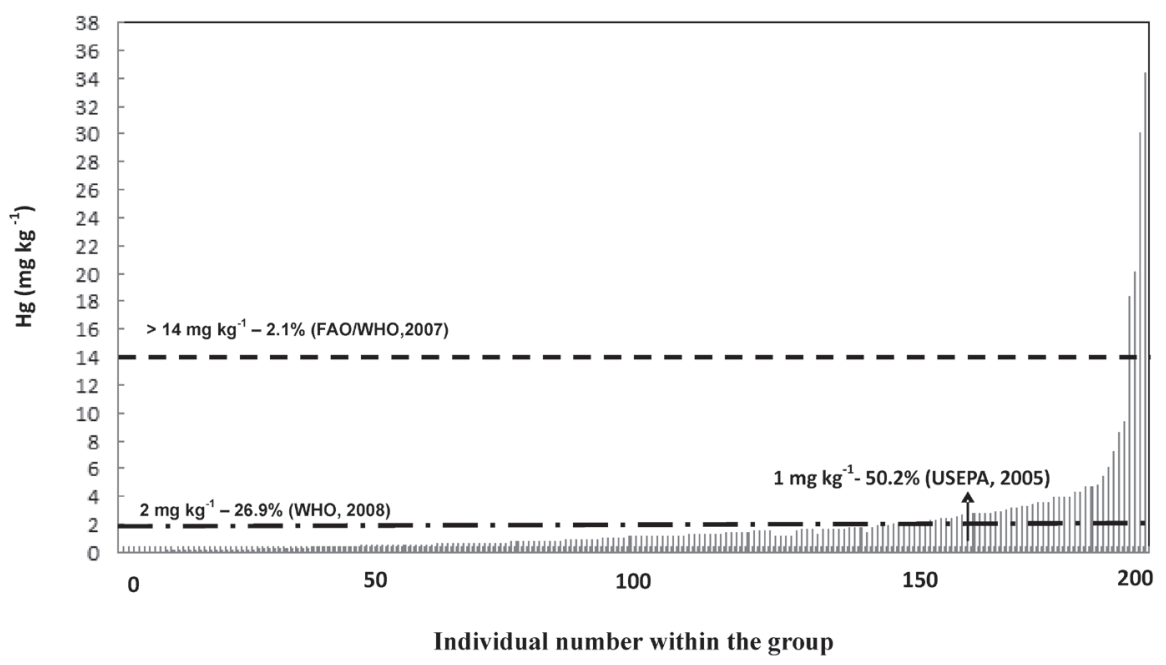

Figure 2 - Distribution of $\mathrm{Hg}$ concentrations in hair of the total study population - $1 \mathrm{mg} \mathrm{kg}^{-1}$ (USEPA, 2005); -.-. : $2 \mathrm{mg} \mathrm{kg}^{-1}$ (WHO, 2008); ----- 14 mg kg-1 (FAO/WHO, 2007).

hair- $\mathrm{Hg}\left(14 \mathrm{mg} \mathrm{kg}^{-1}\right)$ used to determine the recently revised WHO reference dose (FAO/WHO 2007). It should be noted that the above limits refer to adult populations.

The median values for total $\mathrm{Hg}$ in hair samples according to neighborhood were: Alvorada - $\left(1.23 \mathrm{mg} \mathrm{kg}^{-1}\right)$; Cidade Nova - (1.71 $\left.\mathrm{mg} \mathrm{kg}^{-1}\right)$; Compensa - (1.16 $\left.\mathrm{mg} \mathrm{kg}^{-1}\right)$; Flores - $(0.98$ $\left.\mathrm{mg} \mathrm{kg}^{-1}\right)$; Japiim - (1.06 $\left.\mathrm{mg} \mathrm{kg}^{-1}\right)$ and São José $\left(0.16 \mathrm{mg} \mathrm{kg}^{-1}\right)$. Neighborhood $\mathrm{Hg}$ and $\mathrm{MeHg}$ variation results were similar except for the São José neighborhood that presented much lower $\mathrm{Hg}$ levels. It is interesting to note that this neighborhood is the furthest from the city's port which may have an effect on fish acquisition for consumption.

Figure 3 shows the box plots (median) of the total $\mathrm{Hg}$ concentrations in hair in function of social class (B, C, D, E) of the studied population. The median values for total $\mathrm{Hg}$ and $\mathrm{MeHg}$ interval (in \% of total $\mathrm{Hg}$ ) in hair samples for the 


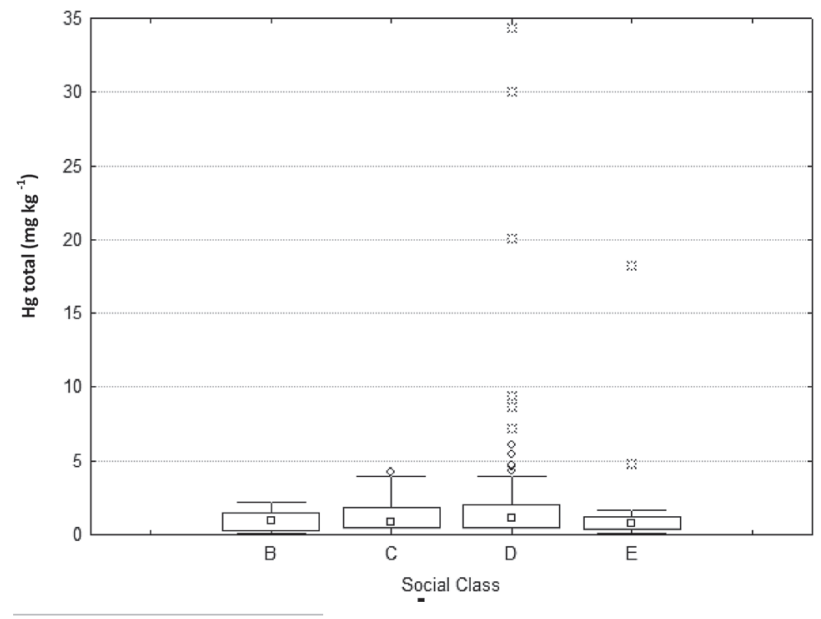

Figure 3 - Box plot of total $\mathrm{Hg}$ distribution as a function of the social class, from Manaus population (mean $+/$ - standard deviation).

studied population according to social classes were: class B (0.92 $\mathrm{mg} \mathrm{kg}^{-1}-71.1$ to $90.6 \%$ for $\left.\mathrm{MeHg}\right)$; class C $(0.86 \mathrm{mg}$ $\mathrm{kg}^{-1}-47.1$ to $93.9 \%$ for $\left.\mathrm{MeHg}\right)$; class D $\left(1.17 \mathrm{mg} \mathrm{kg}^{-1}-\right.$ 46.6 to $98.1 \%$ for $\mathrm{MeHg})$ and class $\mathrm{E}\left(0.77 \mathrm{mg} \mathrm{kg}^{-1}-58.0\right.$ to $90.6 \%$ for $\mathrm{MeHg}$ ).

Total $\mathrm{Hg}$ and $\mathrm{MeHg}$ content were higher in hair for class $\mathrm{D}\left(1.17 \mathrm{mg} \mathrm{kg}^{-1}\right)$. Although medians for total $\mathrm{Hg}$ in hair presented some variation among the studied social classes $(B$, C, D, E), according to the Kruskal-Wallis test the differences between Total $\mathrm{Hg}$ observed in function of social classes were not significant $(\mathrm{p}>0.05)$.

Table 2 shows the total $\mathrm{Hg}$ levels in children hair from several other studies from the Amazon region and São Paulo State (Brazil) and some other countries for the sake of comparison.

\section{Discussion}

Souza and Barbosa's review (2000) of published studies on riverine communities in the Amazon found a mean value of $19.1 \mathrm{mg} \mathrm{kg}^{-1}$ for total $\mathrm{Hg}$ in hair samples, a value considered too high and deserving special attention of the national governmental environmental and health agencies. A more recent review indicates that a wide range of exposure, with mean hair-Hg levels above $15 \mathrm{mg} \mathrm{kg}^{-1}$ in several Amazonian communities has been found, placing them among the highest reported levels in the world (Passos and Mergler 2008). Although there is much conflicting data about $\mathrm{Hg}$ limits in human hair, possibly indicating initial problems due to $\mathrm{Hg}$ exposure, it is well established that fish consumption constitutes the main intake of $\mathrm{Hg}$ in human populations (Marques et al. 2007; Passos et al. 2007b; Díez et al. 2008; Endo and Haraguchi 2010; Freire et al. 2010). The frequency of fish consumption is usually determined by the number of protein options available to a community. Therefore, it can
Table 2 - Comparison of total $\mathrm{Hg}$ levels in children's hair from different localities in Brazil and in other countries

\begin{tabular}{|c|c|c|}
\hline \multirow{2}{*}{ Communities } & \multicolumn{2}{|c|}{ Total Hg (mg kg-1) } \\
\hline & Mean \pm S.D. & Interval \\
\hline $\begin{array}{l}\text { Brasília Legal - age: } 0 \text { - } 5 \text { years old } \\
\text { (Pará State) (Santos et al., 2000) }\end{array}$ & $5.84 \pm 4.91$ & $1.09-20.46$ \\
\hline $\begin{array}{l}\text { Barão do Melgaço - age: } 3 \text { - } 7 \text { years } \\
\text { old (Mato Grosso State) (Tavares et } \\
\text { al., 2005) }\end{array}$ & $5.37 \pm 3.35$ & $0.58-17.14$ \\
\hline $\begin{array}{l}\text { Bacia do Rio Madeira: children and } \\
\text { adults (Amazon region) (Bastos et al., } \\
\text { 2006) }\end{array}$ & $15.22 \pm 9.6$ & $0.36-150.0$ \\
\hline $\begin{array}{l}\text { São Luiz do Tapajós - age: } 0 \text { - } 5 \text { years } \\
\text { old (Pará State) (Santos et al., 2000) }\end{array}$ & $21.06 \pm 14.38$ & $0.10-94.50$ \\
\hline $\begin{array}{l}\text { Waru (Indians from Vila Dr. Tanajura) - } \\
\text { age: } 4 \text { - } 8 \text { years old (Rondônia State) } \\
\text { (Campos et al., 2002) }\end{array}$ & $5.6 \pm 0.8$ & $5.06-6.58$ \\
\hline $\begin{array}{l}\text { Negro River - age: < } 15 \text { years old } \\
\text { (Amazon region) (Barbosa et al., 2001) }\end{array}$ & $18.52 \pm 10.04$ & $0.51-45.89$ \\
\hline $\begin{array}{c}\text { Cubatão city - age: } 1 \text { - } 10 \text { years old } \\
\text { (São Paulo State) } \\
\text { (Santos Filho et al, 1993) }\end{array}$ & $0.82 \pm 0.48$ & $0.2-3.0$ \\
\hline $\begin{array}{l}\text { Cananéia city - age: } 4 \text { - } 12 \text { years (São } \\
\text { Paulo State) (Farias, 2008) }\end{array}$ & $0.48 \pm 0.35$ & $<0.01-3.32$ \\
\hline $\begin{array}{l}\text { Manaus - aged from } 2-7 \text { years } \\
\text { (present study) }(n=201)\end{array}$ & $1.93 \pm 3.90$ & $0.02-34.4$ \\
\hline \multirow{2}{*}{ Other countries } & \multicolumn{2}{|c|}{ Total $\mathrm{Hg}\left(\mathrm{mg} \mathrm{kg}^{-1}\right)$} \\
\hline & Mean \pm S.D. & Interval \\
\hline $\begin{array}{c}\text { Spain - age: } 4 \text { years (Montuori et al., } \\
\text { 2006) }\end{array}$ & $0.99 \pm 0.20$ & $<0.01-5.63$ \\
\hline $\begin{array}{c}\text { Japan - age: } 7 \text { years (Montuori et al., } \\
\text { 2006) }\end{array}$ & $1.4 \pm 0.89$ & $0.45-6.32$ \\
\hline $\begin{array}{l}\text { Africa (Ghana) - age: not cited } \\
\text { (Adimado et al., 2002) }\end{array}$ & $1.93 \pm 1.61$ & $0.62-4.27$ \\
\hline
\end{tabular}

be assumed that low income communities such as Indian and riverine populations have as their primary protein source, fish. Passos and Mergler (2008) cited that among fish consumers, riparian communities present the highest degree of exposure, with mean hair- $\mathrm{Hg}$ as high as $38.6 \pm 14.4 \mathrm{mg} \mathrm{kg}^{-1}$ (Eve et al, $1996)$ and $65 \pm 58 \mathrm{mg} \mathrm{kg}^{-1}$ (Leino et al, 1996). Overall, urban fish-consumers are the least exposed, presenting mean hair- $\mathrm{Hg}$ levels of $2.4 \mathrm{mg} \mathrm{kg}^{-1}$ (Santos et al, 2002), $2 \mathrm{mg} \mathrm{kg}^{-1}$ (Passos et al 2003), and $1.9 \mathrm{mg} \mathrm{kg}^{-1}$ (Webb et al 2004).

In Brazil, there are few studies outside the Amazon region regarding levels of mercury in hair (Table 2).

Santos Filho et al. (1993) assessed lead (Pb) and Hg levels in children's hair from Cubatấo. Hair of 251 children (from 1 to 10 years old) was analyzed by AAS analytical technique. These children residing in 6 neighborhoods on the banks of Cubatâo's main river were chosen and 2 groups were selected: one with high consumption of aquatic organisms from Cubatáo's river and another one consuming no aquatic organism whatsoever. The mean concentration for total $\mathrm{Hg}$ was $0.82 \pm 0.48 \mathrm{mg} \mathrm{kg}^{-1}\left(0.2\right.$ to $\left.3.0 \mathrm{mg} \mathrm{kg}^{-1}\right)$, detected in 
217 children hair samples. No statistical difference $(\mathrm{p}>0.05)$ was observed between the averages found for $\mathrm{Hg}$ in the hair of those who consumed and those who did not consume aquatic organisms.

Farias et al. (2008) performed a study that analyzed children's' hair $(\mathrm{n}=105)$ from three public schools (PSCa1, PSCa2 and PSCa3) (age varying from 4 to 12 years) from Cananéia, São Paulo State, Brazil. In this study, during the hair collection, the children's parents answered a questionnaire about fish weekly intake. The information of the questionnaires revealed that the fish and seafood intake frequency of 1 to 2 times/week was $48 \%, 45 \%$ and $43 \%$ for the PSCa1, PSCa2 and PSCa3, respectively. The $<2$ times/ week frequency was 39, 47 and 50\%, respectively. For the "rarely" choice, the answers were 13, 8 and 7\%, respectively. Generally, the majority of the families that took part of the study, presented a low income level, with the salary in the range of 1 to 5 minimum salaries in Brazil (67.6\%), characterizing a low income population and high consumption of fish and seafood, since these families are generally fishing families. The mean total Hg levels in children's hair from the 3 public schools were: PSCa1, $151 \pm 216 \mu \mathrm{g} \mathrm{kg}^{-1}$ (interval: $<10-770$, median: $43 \mu \mathrm{g} \mathrm{kg}^{-1}$ ); PSCa2, $505 \pm 536 \mu \mathrm{g} \mathrm{kg}^{-1}$ (interval: $<10$ - 3321, median: $389 \mu \mathrm{g} \mathrm{kg}^{-1}$ ) and PSCa3, $554 \pm 547 \mu \mathrm{g} \mathrm{kg}^{-1}$ (interval: $<10-2814$, median: $394 \mu \mathrm{g} \mathrm{kg}^{-1}$ ).

Total $\mathrm{Hg}$ levels in children's hair from Manaus were lower when compared to those values obtained from children living in other localities of the Amazon region. However, the values observed in this study were higher when compared to children's $\mathrm{Hg}$ hair values living in other regions of the country, and very similar to the values of other published results from countries such as Japan and Ghana (Table 2), in spite of some differences in age between the participants. In these different studies, fish consumption was often cited as the most significant factor for the bioaccumulation of mercury, particularly in its organic form. The results of this study corroborated with the results obtained in several recent studies between total $\mathrm{Hg}$ and $\mathrm{MeHg}$ concentrations in hair samples and eating habits (Santos et al. 2000; Marques et al. 2007; Hacon et al. 2008; Passos and Mergler 2008).

It should also be noted that $\mathrm{Hg}$ levels determined in 12 fish species most consumed by the Manaus population (750 $\pm 773 \mu \mathrm{g} \mathrm{kg}^{-1}$, range $30-2392 \mu \mathrm{g} \mathrm{kg}^{-1}$, dry weight) in a recent study developed by Farias et al., (2010), showed higher $\mathrm{Hg}$ levels than those of the most consumed fish species of the Cananéia population $\left(332 \pm 457 \mu \mathrm{g} \mathrm{kg}^{-1},<10-2008 \mu \mathrm{g} \mathrm{kg}^{-1}\right.$, dry weight) (Curcho et al. 2009). These findings could also justify the higher Hg levels found in children's hair of the present study.

As already known, it is also important to consider cultural, nutritional, socio-economic and demographical factors, all of which can influence dietary habits which in turn can affect $\mathrm{Hg}$ intake. According to the POF 2003-2004 data, for a diet of $1,883.89 \mathrm{kcal} /$ day, relative participation of fish in the total kcal for the northern region was $3.07 \%$. The consumption of meat and chicken was $9.32 \%$ for the same region. In comparison, the southern region of the country presents a value of $0.23 \%$ for the same diet $\left(1,883.89 \mathrm{kcal} \mathrm{day}^{-1}\right)$ considering fish consumption. This is also true for other regions of Brazil. The POF study further reveals a greater acquisition of fresh fish for the northern region $(7.48 \%)$, which is much higher than other regions. Thus, from the data a 1,659.95 kcal day ${ }^{-1}$ diet, the relative consumption of fish for the urban area was $2.11 \%$. For rural areas, a 2,524.55 kcal day ${ }^{-1}$ diet, the relative fish consumption was $4.89 \%$, indicating a greater consumption of fish in rural areas for the northern region. Furthermore, published studies reveal that the average fish consumption per capita in Manaus is between 100 to $200 \mathrm{~g} /$ day (36 to 72 $\mathrm{kg}$ year $\left.^{-1}\right)$ (Val and Santos 2009).

A confirmation for the $\mathrm{Hg}$ levels in children's hair of this study may also be found in the POF report. POF verifies that families with higher income levels consume more meat and chicken than fish. On the other hand, more fish consumption is seen in families with lower income levels. In the present study class $\mathrm{D}$ presented the highest $\mathrm{Hg}$ level in hair samples (median value of $1.17 \mathrm{mg} \mathrm{kg}^{-1}$ ), confirming the above mentioned hypothesis.

In regards to fish intake frequency, the Manaus city population does not consume as much fish as the riverine populations and Indians, since they can substitute fish for other protein sources. Furthermore, fish consumption for the Manaus population depends on seasonality, thus depending on the period of the year, the consumption of fish drops drastically due to the rise in fish prices.

\section{CONCLUSIONS}

Despite the fact that the Manaus population consume fish as part of its normal dietary intake, $\mathrm{Hg}$ hair levels were lower when compared to other localities from the Amazon region, but higher than the mean levels from other regions of Brazil such as Cananéia and Cubatão, coastal cities and similar to other studies from other countries (Japan and Ghana). The most consumed fish species by the Manaus population presented higher $\mathrm{Hg}$ levels than the species most consumed by Cananéia population. If fish consumption is low, it stands to reason that $\mathrm{Hg}$ exposure should also be less. This is especially true when a population has other protein sources as options for its diet. In the case of this study this was confirmed by the IBGE's POF, which also showed the importance of fish as a protein source for Brazilian Northern populations. In the present study class D presented the highest $\mathrm{Hg}$ level in 
hair samples (median value of $1.17 \mathrm{mg} \mathrm{kg}^{-1}$ ), confirming the hypothesis previously mentioned.

\section{ACKNOWLEDGMENTS}

The authors wish to thank CAPES for financial support and the INPA Food and Nutrition Laboratory, (Amazon National Research Institute), for the hair samples.

\section{REFERENCES}

ABEP, Associação Brasileira de Empresas de Pesquisa (ABEP) 2003. Critério Classificação Econômica Brasil, p. 1 - 23.

Adimado, A.A.; Baah, D.A. 2002. Mercury in human blood, urine, hair, nail, and fish from the Ankobra and Tano River Basins in southwestern Ghana. Bulletin Environmental Contamination Toxicology, 68: 339-346.

Barbosa, A.C.; Jardim, W.; Dorea, J.G.; Fosberg, B.; Souza J. 2001 Hair mercury speciation as a function of gender, age and body mass index in inhabitant of the Negro River Basin, Amazon, Brazil. Archives of Environmental Contamination and Toxicology, 40: $439-444$

Bastos, W.R.; Gomes, J.P.O.; Oliveira, R.C.; Almeida, R.; Nascimento, E.L.; Bernardi, J.V.E. 2006. Mercury in the environment and riverside population in the Madeira River Basin, Amazon, Brazil. Science of the Total Environment, 368: $344-351$.

Campos, M.S. 2001. Estudo da correlação mercúrio-selênio em amostras de cabelos de indios Wari. Dissertaçáo (Mestrado), Instituto de Pesquisas Energéticas e Nucleares, IPEN, São Paulo. 200 pp.

Campos, M.S.; Sarkis, J.E.S.; Muller, R.C.S.; Brabo, E.S.; Santos, E.O. 2002. Correlation between mercury and selenium concentrations in Indian hair from Rondônia State, Amazon region, Brazil. Science of the Total Environment, 287: 155-161.

Curcho, M.R.M.S.; Farias, L.A.; Baggio, S.R.; Fonseca, B.C.; Nascimento, S.M.; Bortoli, M.C.; Braga, E.S.; Favaro, D.I.T. 2009. Mercury and methylmercury content, fatty acids profile, and proximate composition of consumed fish in Cananéia, São Paulo, Brazil. Revista do Instituto Adolfo Lutz (Impresso), 68(3): 442-450.

Díez, S.; Montuori, P.; Pagano, A.; Sarnacchiaro, P.; Bayona, J.M.; Triassi, M. 2008. Hair mercury levels in an urban population from southern Italy: Fish consumption as a determinant of exposure. Environmental International, 34: 162-167.

Dorea, J.G. 2003. Fish are central in the diet of Amazonian riparians: should we worry about their mercury concentrations? Environmental Research, 92: 232-244.

Dorea, J.G.; Souza, J.R.; Rodrigues, P.; Ferrari, I.; Barbosa, A.C. 2005. Hair mercury (signature of fish consumption) and cardiovascular risk in Mundurubu and Kayabi Indians of Amazonia. Environmental Research, 97: 209-219.

Endo, T.; Haraguchi, K. 2010. High mercury levels in hair samples from residents of Taiji, a Japanese whaling town. Marine Pollution Bulletin, 60(5): 743-7.
Eve, E.; Oliveira, E.F.; Eve, C. 1996. The mercury problem and diets in the Brazilian Amazon: planning a solution. Environmental Conservation. 23: 133-9.

FAO/WHO Expert Committee on Food Additives. Sixty-first meeting. Summary and conclusions. ftp://ftp.fao.org/es/esn/jecfa/ jecfa61sc.pdf (accessed on 21/05/2007).

Farias, L.A.; Santos, N.R.; Fávaro, D.I.T.; Braga, E.S. 2008. Mercúrio total em cabelo de crianças de uma população costeira, Cananéia, São Paulo, Brasil. Cadernos de Saúde Pública, 24(10): 2249-56.

Farias, L.A.; Fávaro, D.; Vasconcellos, M.B. 2009. Determinação de Mercúrio e Metilmercúrio em Amostras de Cabelo e Peixes. Revista do Instituto Adolfo Lutz, 68(3): 451-460.

Farias, L.A.; Fávaro, D. I.; Santos, J.O.; Vasconcellos, M.B.; Pessoa, A., Aguiar, J.; YuYama, L. 2010. Cooking process evaluation on mercury content in fish. Acta Amazonica, 40(4): 741 - 748.

Freire, C; Ramos. R.; Espinosa, M-J.L.; Díez, S., Vioque, J.; Ballester, F.; Fernández, M. 2010. Hair mercury levels, fish consumption, and cognitive development in preschool children from Granada, Spain. Environmental Research, 110 (1): 96-104.

Guentzel, J.L.; Portilla, E.; Keith, K.M.; Keith, E.O. 2007. Mercury transport and bioaccumulation in riverbank communities of the Alvarado Laggon System, Veracruz State, Mexico. Science of the Total Environment, 308: 316-324

Hacon, S.; Barrocas, P.R.G.; Vasconcellos, A.C.S.; Barcellos, C.; Wasserman, J.C.; Campos, R.C.; Ribeiro, R.; Azevedo-Carloni, F.B. 2008. An overview of Mercury contamination research in the Amazon basin with an emphasis on Brazil. Cadernos Saúde Pública, Rio de Janeiro, 24 (7): 1479-1492.

Horvat, M. Mercury analysis and speciation. In Environmental Sample in Global and Regional Marcury Cycles: Sources, Fluxes and Mass Balances, p. 1-31, W. Baeyens (eds), 1996.

IAEA, 1987. International Atomica Energy Agency. Reference Methods for Marine Pollution Studies. Vienna, IAEA, (IAEA-MEL-46).

IBGE, 2004. Instituto Brasileiro de Geografia e Estatística. Pesquisa de Orçamentos Familiares 2002/2003.

IBGE, 2010. Instituto Brasileiro de Geografia e Estatística. IBGE Cidades@. (http://www.ibge.gov.br). Accessed in 05/02/2011.

Leino, T.; Lodenius, M. 1995. Human hair Mercury levels in Tucuruí area, State of Pará, Brazil. Science of the Total Environment, 175: 119-25.

Marques, R.C.; Dórea, J.G.; Bastos, W.R.; Rebelo, M.F.; Fonseca, M.F.; Malm, O. 2007. Maternal mercury exposure and neuromotor development in breastfed infants from Porto Velho (Amazon), Brazil. International Journal Hygiene Environmental Health, 210: 51-60.

Montuori, P.; Jover, E.; Díez, S.; Riba-Fitó, N.; Sunyer, J.; Triassi, M.; Bayona, J. M. 2006. Mercury speciation in the hair of preschool children living near a chlor-alkali plant. Science of the Total Environment, 369: 51-58.

Passos, C.J.S.; Lucotte, M.; Queiroz, A.; Mergler, D.; Peleja, R.; Goch, Y. et al. 2003. Condições socioeconômicas e exposição ao mercúrio $(\mathrm{Hg})$ através do consumo de peixe: um estudo de caso em Santarém, Pará, Brasil. Revista Saúde Ambiente, 6:3-11. 
Passos, C.J.S.; Mergler, D.; Lemire, M.; Fillion, M.; Guimarães, J.RD. 2007a. Fish consumption and bioindicators of inorganic mercury exposure. Science of the Total Environment, 373: 68-76.

Passos, C.J.S.; Sampaio, D., Lemire, M., Fillion, M., Davée, J.R., Lucotte, M., Mergler, D. 2007b. Daily mercury intake in fisheating populations in the Brazilian Amazon. Journal of Exposure Science and Environmental Epidemiology , 1: 1-12.

Passos, C.J.S.; Silva, D.S., Lemire, M., Fillion, M., Guimarães, J.R.D., Lucotte, M., Mergler, D. 2008. Daily mercury intake in fish-eating populations in the Brazilian Amazon. Journal of Exposure Science and Environmental Epidemiology, 18: 76-87.

Passos, C.J.S.; Mergler, D. 2008. Human Mercury exposure and adverse health effects in the Amazon: a review. Cadernos de Saúde Pública, Rio de Janeiro, 24 Sup.4: S503-S520.

Roulet, M.; Lebel, J.; Mergler, D.; Lucotte M; Larribe, F. 1997. Fish diet and mercury exposure in a riparian Amazonian population. Water Air Soil Poll, 97: 31-44.

Santos Filho; E., Silva, R.S.; Sakuma, A.M.; Scorsafava, M.A. 1993. Teores de chumbo e mercúrio em cabelo de crianças residentes em Cubatão, na região Sudeste do Brasil. Revista de Saúde Pública, 27(2): 81-86.

Santos, L.S.N.; Muller, R.; Sarkis, J.E.S.; Alves, C.N.; Brabo, E.S.; Santos, E.O.; Bentes, M.H. 2000. Evaluation of total mercury concentrations in fish consumed in the municipality of Itaiba, Tapajós's River Basin, Pará, Brazil. Science of the Total Environment, 261: 1-8.

Santos, E.C.O.; Jesus, I.M.; Brabo, E.S.; Loureiro, E.C.B.; Mascarenhas, A.F.S.; Weirich, J. 2000. Mercury exposures in riverside Amazon communities in Pará, Brazil. Environmental Research, 84: 100-107.

Santos, E.O.; Jesus, I.M; Brabo, E.S.; Jesus, Câmara, V.M.; Loureiro, E.C.B; Mascarenhas, A.F. et al. 2002. Exposure to Mercury in the urban population of Rio Branco City, State of Acre, Brazil. Bulletin of Environmental Contamination and Toxicology, 69: 314-9.

Santos, E.O.; Jesus, I.M; Câmara, V.M.; Brabo, E.S.; Jesus, M.I.; Fayal, K.F. 2007. Correlation between blood mercury levels in mothers and newborns in Itaituba, Pará State, Brazil. Cadernos de Saúde Pública, 23(4): S622-S629.
Segall-Corrêa A.M; Pérez-Escamilia R.; Maranha L.K.; Sampaio M.F.A.; Yuyama L.; Alencar F; et al. 2003. Projeto: Acompanhamento e Avaliação da Segurança Alimentar de Famílias Brasileiras: validação de metodologia e de instrumento de coleta de informação. Campinas: Departamento de Medicina Preventiva e Social, Universidade Estadual de Campinas/Organizaçáo PanAmericana da Saúde/Ministério de Saúde (Relatório Técnico).

Souza, J.R.; Barbosa, A.C. 2000. Contaminaçáo por Hg e o caso da Amazônia. Química Nova na Escola, 12: 23-25.

Tavares, L.M.B.; Câmara, V.M.; Malm, O.; Santos, E.C.O. 2005. Performance on neurological development tests by riverine children with moderate mercury exposure in Amazonia, Brazil. Cadernos de Saúde Pública, 21(4): 1160-1167.

USEPA, 2005. (US. Environmental Protection Agency, Office of Science and Technology, Office of Water) Water quality criterion for the protection of human health. Methylmercury. (www.epa.gov/ waterscience/criteria/methylmercury/document.html). Acesso em 01/02/2011.

Val, A.L.; Santos, G.M. 2009. Grupo de Estudos Estratégicos Amazônicos - TOMO 2 In Ferreira, E.F.J.G. Recursos pesqueiros: uma análise conjuntural, Editora INPA, p. 19-66, ISBN: 97885-211-0038-6.

Webb, J.; Mainville, N.; Lucote, M.; Betancourt, O.; Davidson, R. et al. 2004. Mercury in fish-eating communities of the Andean Amazon, Napo River Valley, Ecuador. Ecohealth 1 Suppl. 2: 59-71.

WHO, 2008. Issued by UNEP DTIE Chemicals Branch and WHO Department of Food Safety, Zoonoses and Foodborne Diseases. (http://www.who.int/foodsafety/publications/chem/ mercuryexposure.pdf). Accessed in 05/08/2011.

Recebido em 04/02/2011

Aceito em 07/07/2011 